\title{
Inkluzja społeczeństwa obywatelskiego w procesy podejmowania decyzji na poziomie lokalnym: wpływ projektów międzynarodowych
}

\begin{abstract}
Streszczenie: Celem artykułu jest wyodrębnienie czynników, które mają bezpośredni wpływ na poziom uczestnictwa mieszkańców w procesach administracyjnych, oraz opracowanie propozycji, które zapewnią systematyczne stosowanie mechanizmów włączenia społeczności lokalnej do podejmowania decyzji. Obecnie na Ukrainie trwają procesy decentralizacji, które mają na celu podwyższenie poziomu zarządzania, w związku z czym odbyło się łączenie rad miejskich i wiejskich. Znaczący wpływ na te procesy mają projekty międzynarodowe, pomagające nowoutworzonym hromadom (jednostka podziału administracyjnego) wprowadzać lepsze praktyki zarządzania, zwłaszcza poprzez włączenie społeczeństwa obywatelskiego do podejmowania decyzji na poziomie lokalnym. Problem polega na tym, że mieszkańcy z jednej strony nie wiedzą, jakie istnieją mechanizmy uczestnictwa w procesach administracyjnych, a $z$ drugiej strony - władze lokalne niewystarczająco informują o możliwościach włączenia społeczeństwa do podejmowania decyzji. W niniejszej pracy zastosowano dwie główne techniki badawcze: wywiad i ankietowanie. Analiza została przeprowadzona na przykładzie nowoutworzonych hromad, które uczestniczyły w Programie „Decentralizacja przynosi lepsze wyniki i efektywność" (DOBRE), realizowanym przez międzynarodową organizację Global Communities i finansowanym ze środków Agencji Stanów Zjednoczonych ds. Rozwoju Międzynarodowego (USAID). Ustalono, że mieszkańcy nie są wystarczająco zorientowani w mechanizmach umożliwiających im uczestnictwo w procesach podejmowania decyzji na szczeblu lokalnym oraz możliwości ich wykorzystania. Ponadto stwierdzono, że istnieje związek wzajemny: im wyższy poziom wiedzy społeczeństwa obywatelskiego (jak otrzymać dostęp do informacji o usługach, za które odpowiadają władze lokalne), tym wyższy poziom jego zadowolenia z uczestnictwa w podejmowaniu decyzji. Potencjalnym zagrożeniem po zakończeniu projektów międzynarodowych może być cofnięcie w przemianach, które zostały wprowadzone w hromadach. W celu uniknięcia takiej sytuacji może być zaproponowane stworzenie w strukturze jednostek samorządowych osobnego wydziału odpowiadającego za wdrożenie przemian w hromadach albo przegląd funkcji już istniejących wydziałów, ich reformowanie i wprowadzenie „dobrych praktyk” dla monitoringu, analizy, zbioru danych oraz stworzenie warunków dla wewnętrznej koordynacji kierunków rozwoju.
\end{abstract}

Slowa kluczowe: samorząd, partycypacja obywatelska, reforma, decentralizacja

\section{Wprowadzenie}

$\mathbf{W}$ procesach wprowadzenia reformy decentralizacji na Ukrainie ważną rolę odgrywa aktywizacja społeczeństwa obywatelskiego, podwyższenie poziomu odpowiedzialności zarówno władzy lokalnej, jak i mieszkańców. Jak zaznacza Liubow Bevzenko, jeśli dość łatwo można nauczyć organizacyjnych metod zarządzania, to zasady samoorganizacji wyglądają na prostsze w ich płaszczyźnie teoretycznej, lecz w realnych technologiach społecznych ich realizacja jest znacząco mniej oczywista. Z naszego punktu widzenia, droga do takich technologii polega przede wszystkim na zmianie podstawowych umiejętności zarządzania, dlatego bardziej skoncentrujemy swoją uwagę na rozpatrzeniu tych kluczowych elementów, które tworzą system reprezentacji osób podejmujących decyzje administracyjne (Bevzenko, 2002, s. 173-174). 
Istnieją różne formy udziału mieszkańców w procesach podejmowania decyzji. Wytyczne w sprawie udzialu społeczeństwa obywatelskiego w podejmowaniu decyzji politycznych Rady Europy wyznaczają 4 formy: 1) informowanie; 2) konsultacje; 3) dialog; 4) partnerstwo (Public Participation in Decision-Making Processes..., 2012, s. 19-20). Każda z nich ma swoją charakterystykę i instrumenty (mechanizmy) udziału mieszkańców. Program DOBRE podczas badania opinii publicznej zawarł w ankiecie 9 mechanizmów udziału mieszkańców w podejmowaniu decyzji administracyjnych: budżet partycypacyjny; Młodzieżowa Rada Społeczna; organy samoorganizacji mieszkańców; Rada Społeczna; e-petycje; ekspertyza społeczna; konsultacje społeczne; wysłuchania społeczne; ogólne zebranie mieszkańców (Analiza ankietowania..., 2020, s. 1-12). Praca autorki niniejszego artykułu jako managera projektu w ramach Programu DOBRE pozwoliła na prześledzenie procesów przemian i wyodrębnienie czynników, które mogą sprzyjać utrwaleniu pozytywnych przemian w samorządach, zwłaszcza procesów włączenia mieszkańców do podejmowania decyzji oraz stałego rozwoju w 11 nowoutworzonych hromadah w obwodzie Mikołajowskim.

\section{Badanie opinii publicznej (organizacja GfK Ukraine na zamówienie Programu DOBRE)}

W latach 2017-2018 organizacja GfK Ukraine na zamówienie Programu DOBRE przeprowadziła badanie opinii publicznej w 50 nowoutworzonych hromadach w 7 obwodach na Ukrainie (Public Opinion Research..., 2018, s. 2). Rys. 1 przedstawia zwią-

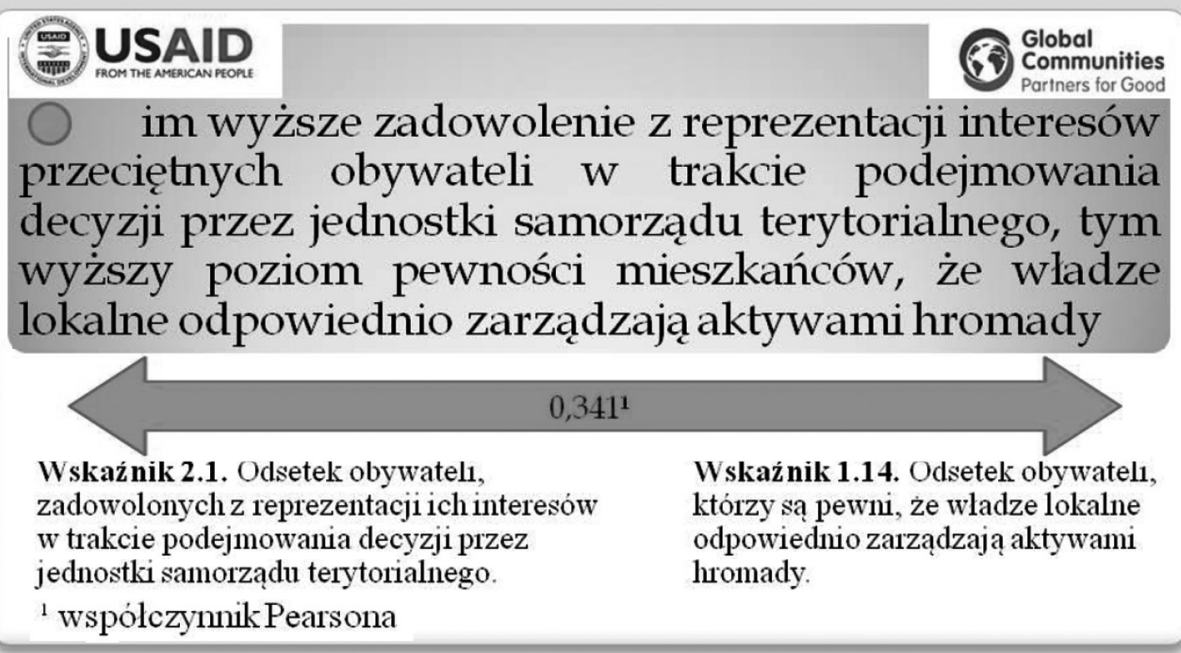

Rys. 1. Związek pomiędzy reprezentacją interesów przeciętnych obywateli podczas podejmowania decyzji przez jednostki samorządu terytorialnego i przekonaniem mieszkańców, że władza lokalna odpowiednio zarządza aktywami hromady

Źródło: Badanie opinii publicznej w celu oceny podstawowego poziomu rozwoju hromad, biorących udział w Programie „Decentralizacja przynosi lepsze wyniki i efektywność” (DOBRE), realizowanym przez międzynarodową organizację Global Communities i finansowanym ze środków Agencji Stanów Zjednoczonych ds. Rozwoju Międzynarodowego (USAID). Opracowanie GfK Ukraine, Wydział Badań Socjalnych i Politycznych, 26.10.2018. 
zek pomiędzy reprezentacją interesów przeciętnych obywateli podczas podejmowania decyzji przez jednostki samorządu terytorialnego i przekonaniem mieszkańców, że władza lokalna odpowiednio zarządza aktywami hromady.

W wyniku przeprowadzonego badania ustalono związek wzajemny: im wyższe zadowolenie $\mathrm{z}$ reprezentacji interesów przeciętnych obywateli $\mathrm{w}$ trakcie podejmowania decyzji przez jednostki samorządu terytorialnego, tym wyższy poziom pewności mieszkańców, że władze lokalne odpowiednio zarządzają aktywami hromady. Na rys. 2 odzwierciedlono związek między wiedzą na temat tego, jak otrzymać dostęp do informacji o usługach, za które odpowiadają władze lokalne, i zadowoleniem mieszkańców z reprezentacji interesów przeciętnych obywateli w trakcie podejmowania decyzji przez organy samorządu terytorialnego.

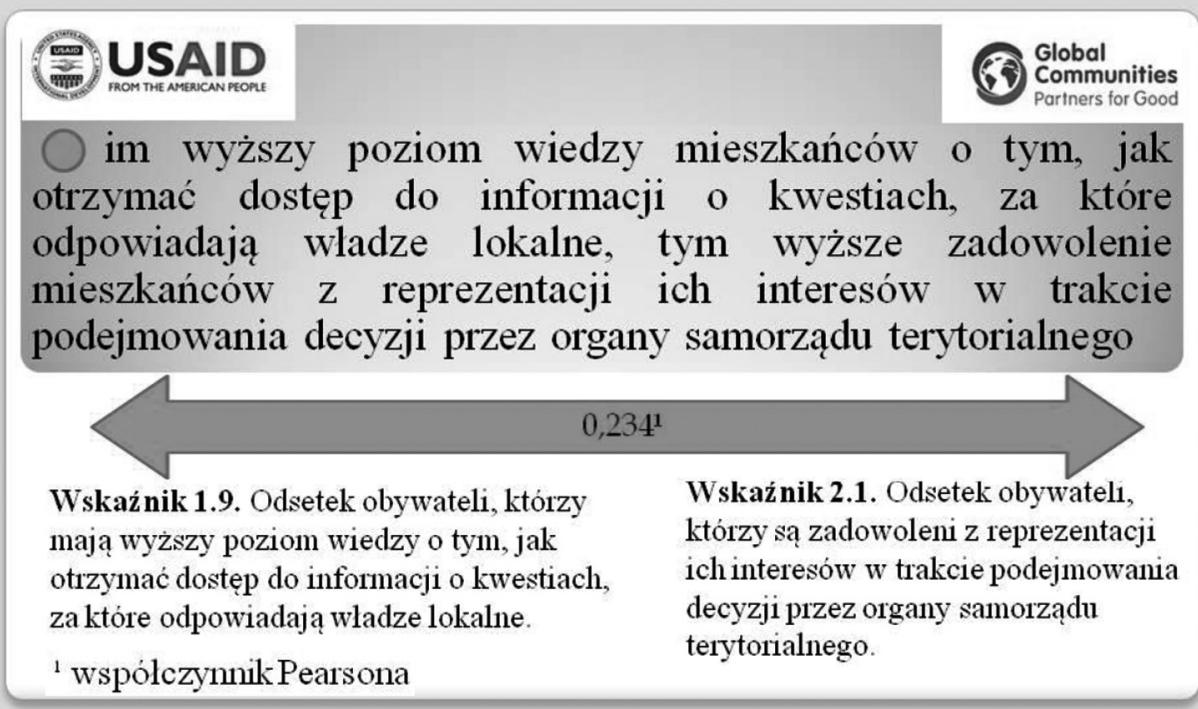

Rys. 2. Związek między wiedzą na temat tego, jak otrzymać dostęp do informacji o usługach, za które odpowiadają władzy lokalne, i zadowoleniem mieszkańców z reprezentacji interesów przeciętnych obywateli w trakcie podejmowania decyzji przez organy samorządu terytorialnego

Źródło: Badanie opinii publicznej w celu oceny podstawowego poziomu rozwoju hromad, biorących udział w Programie „Decentralizacja przynosi lepsze wyniki i efektywność” (DOBRE), realizowanym przez międzynarodową organizację Global Communities i finansowanym ze środków Agencji Stanów Zjednoczonych ds. Rozwoju Międzynarodowego (USAID). Opracowanie GfK Ukraine, Wydział Badań Socjalnych i Politycznych, 26.10.2018.

Jak wynika z danych umieszczonych na rys. 2 powstaje następujący związek: im wyższy poziom wiedzy mieszkańców o tym, jak otrzymać dostęp do informacji o kwestiach, za które odpowiadają władze lokalne, tym wyższe zadowolenie mieszkańców z reprezentacji interesów przeciętnych obywateli w trakcie podejmowania decyzji przez organy samorządu terytorialnego.

Na ogół, odsetek osób, zadowolonych z reprezentacji interesów mieszkańców w trakcie podejmowania decyzji przez organy samorządu terytorialonego, wyniósł 19\%. Na 
pytanie „Na ile dostateczne są możliwości, które władze lokalne w Państwa hromadzie zapewniają obywatelom do uczestnictwa w podejmowaniu decyzji w ciągu ostatnich 12 miesięcy?" otrzymano odpowiedzi: dostateczne możliwości - 19\%, niedostateczne $-31 \%$; grupa kontrolna wskazała: dostateczne $-12 \%$, niedostateczne $-38 \%$.

Na pytanie „Jak często w Państwa hromadzie interesy przeciętnych obywateli są reprezentowane przez samorząd lokalny w trakcie podejmowania decyzji?" odpowiedzi wyglądały następująco: stale $-3 \%$, często $-13 \%$, czasami $-33 \%$, rzadko $-22 \%$, nie wiem $-16 \%$, odmowa odpowiedzi $-13 \%$.

\section{Ankietowanie mieszkańców hromad w obwodzie Mikołajowskim, które uczestniczyły w Programie DOBRE}

W latach 2019-2020 w hromadach obwodu Mikołajowskiego, biorących udział w Programie DOBRE, z inicjatywy autorki artykułu oraz przy jej aktywnym udziale (pomysł, przygotowanie ankiet, organizacja ankietowania, przygotowanie analizy) zostało przeprowadzone badanie ankietowe mieszkańców. Dotyczyło ono wdrożenia mechanizmów uczestnictwa społeczności w podejmowaniu decyzji na szczeblu lokalnym. Udział w badaniu wzięło 1259 respondentów z 11 hromad. Były to osoby, które zamieszkują w 36 miejscowościach należących do wspomnianych hromad (Analiza ankietowania..., 2020, s. 1-12)1. Pierwsza część ankiety zawierała pytania dotyczące informacji personalnych osób biorących udział w badaniu. Wykres 1. przedstawia podział respondentów ze względu na płeć.

\section{Wykres 1. Podział respondentów ze względu na płeć, \%}

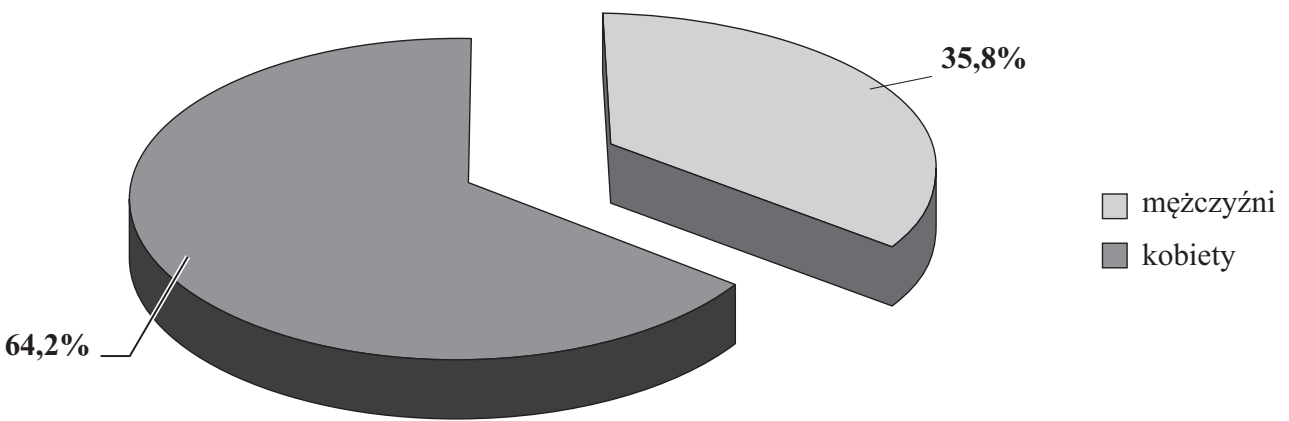

Źródło: Opracowanie własne - Atnazheva L. (2020), Analiza ankietowania mieszkańców hromad terytorialnych obwodu Mikolajowskiego, biorących udział w Programie „Decentralizacja przynosi lepsze wyniki i efektywność” (DOBRE), realizowanym przez międzynarodową organizację Global Communities i finansowanym ze środków Agencji Stanów Zjednoczonych ds. Rozwoju Międzynarodowego (USAID).

${ }^{1}$ Badanie ankietowe mieszkańców miało miejsce podczas przeprowadzenia akcji informacyjnych ,Jest to o nas!”, które dotyczyły promowania nowostworzonych logotypów hromad. Ankietowanie miało formę anonimową, respondenci byli znajdowani w miejscach największego skupienia ludzi (w pobliżu sklepów, bazarów, szkół, oddziałów poczty itd.), a także bezpośrednio na ulicach miast i wsi. 
W strukturze ogólnej ilości respondentów odsetek mężczyzn wyniósł 35,8\%, a kobiet $-64,2 \%$. Podział respondentów odpowiednio do wieku odzwierciedla wykres 2 . Przedstawia on grupy wiekowe respondentów, wśród których znalazły się osoby powyżej 14 roku życia.

\section{Wykres 2. Podział respondentów ze względu na wiek, \%}

\section{$13,7 \%$}

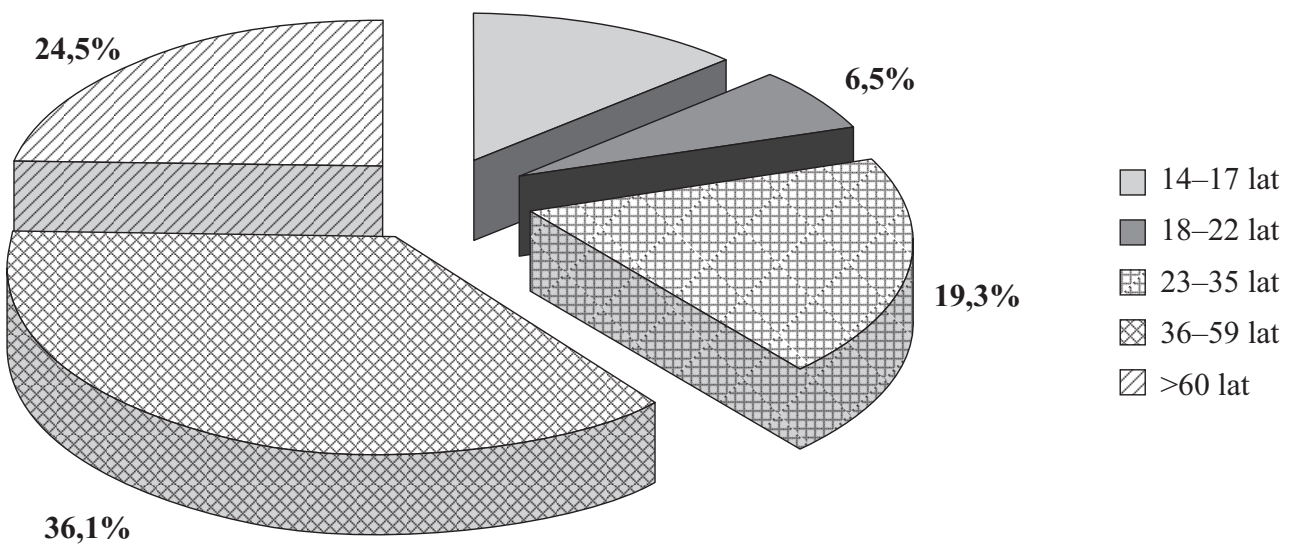

Źródło: Opracowanie własne - Atnazheva L. (2020), Analiza ankietowania mieszkańców hromad terytorialnych obwodu Mikołajowskiego, biorących udział w Programie „Decentralizacja przynosi lepsze wyniki i efektywność" (DOBRE), realizowanym przez międzynarodową organizację Global Communities i finansowanym ze środków Agencji Stanów Zjednoczonych ds. Rozwoju Międzynarodowego (USAID).

Na pytanie ,Jakie mechanizmy włączania mieszkańców do procesów podejmowania decyzji funkcjonują w Państwa hromadzie?" respondenci dosyć często wskazywali te, które w samorządach lokalnych nie funkcjonują. Świadczy to o braku wiedzy społeczności na temat tego, jak działają takie mechanizmy i co się pod nimi kryje. Dla wizualnego odzwierciedlenia „błędnej wiedzy” respondentów na wykresie 3 została przedstawiona struktura mechanizmów włączania społeczności do podejmowania decyzji w hromadach zgodnie z faktycznymi odpowiedziami oraz zmodelowano strukturę, która mogłaby mieć miejsce, gdyby wszyscy respondenci udzielili właściwych odpowiedzi.

Należy wspomnieć, że w ramach działalności programowej regularnie monitorowany jest proces wdrożenia mechanizmów uczestnictwa mieszkańców w podejmowaniu decyzji administracyjnych. Ponadto na bieżąco jest aktualizowana informacja o stanie wdrożenia poszczególnych mechanizmów w każdej z 11 hromad.

Najczęściej respondenci mylili takie mechanizmy, jak „Rada Społeczna” i ,ekspertyza społeczna”. Wykres 4 przedstawia odpowiedzi respondentów w zestawieniu $\mathrm{z}$ faktycznym stanem funkcjonowania omawianych mechanizmów w jednej z badanych jednostek podziału administracyjnego, a dokładnie w Prybużaniwskiej Radzie Wiejskiej.

Podobny schemat został wykorzystany podczas analizy odpowiedzi respondentów na pytanie: „Jakie mechanizmy uczestnictwa mieszkańców w podejmowaniu decyzji admi- 
Wykres. 3. Odpowiedzi respondentów na temat mechanizmów uczestnictwa mieszkańców w podejmowaniu decyzji administracyjnych, które funkcjonują w 11 hromadach obwodu Mikolajowskiego, \%

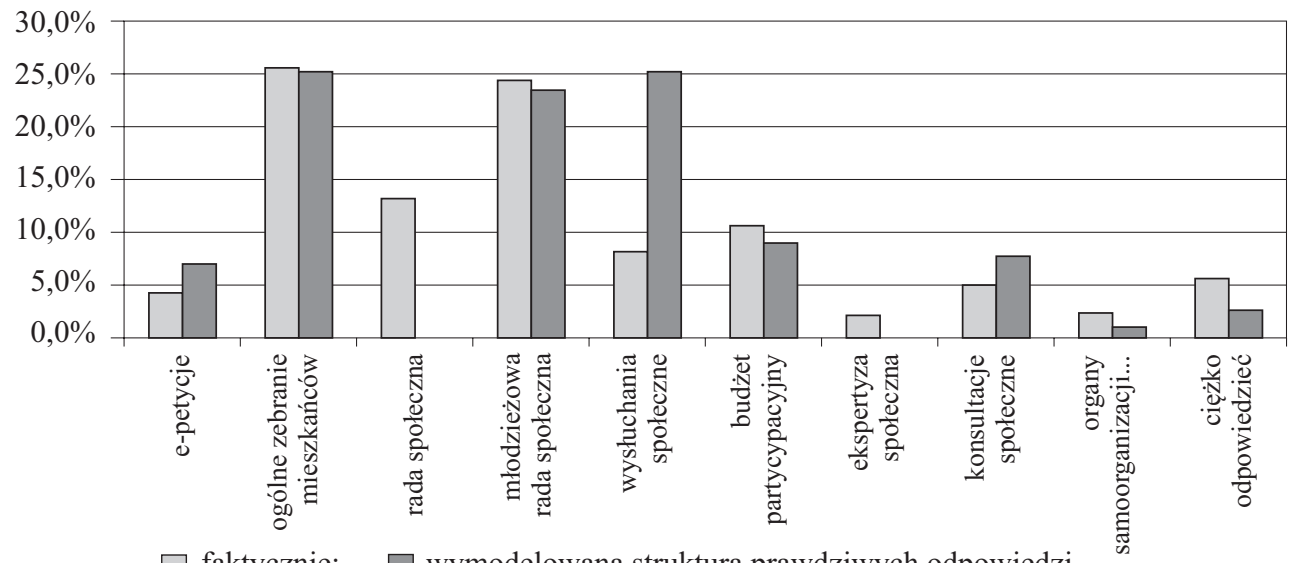

Źródło: Opracowanie własne - Atnazheva L. (2020), Analiza ankietowania mieszkańców hromad terytorialnych obwodu mikołajowskiego, biorących udział w Programie „Decentralizacja przynosi lepsze wyniki i efektywność" (DOBRE), realizowanym przez międzynarodową organizację Global Communities i finansowanym ze środków Agencji Stanów Zjednoczonych ds. Rozwoju Międzynarodowego (USAID).

Wykres 4. Odpowiedzi respondentów na temat mechanizmów uczestnictwa mieszkańców w podejmowaniu decyzji administracyjnych, które funkcjonują w Prybużaniwskiej Radzie Wiejskiej, \%

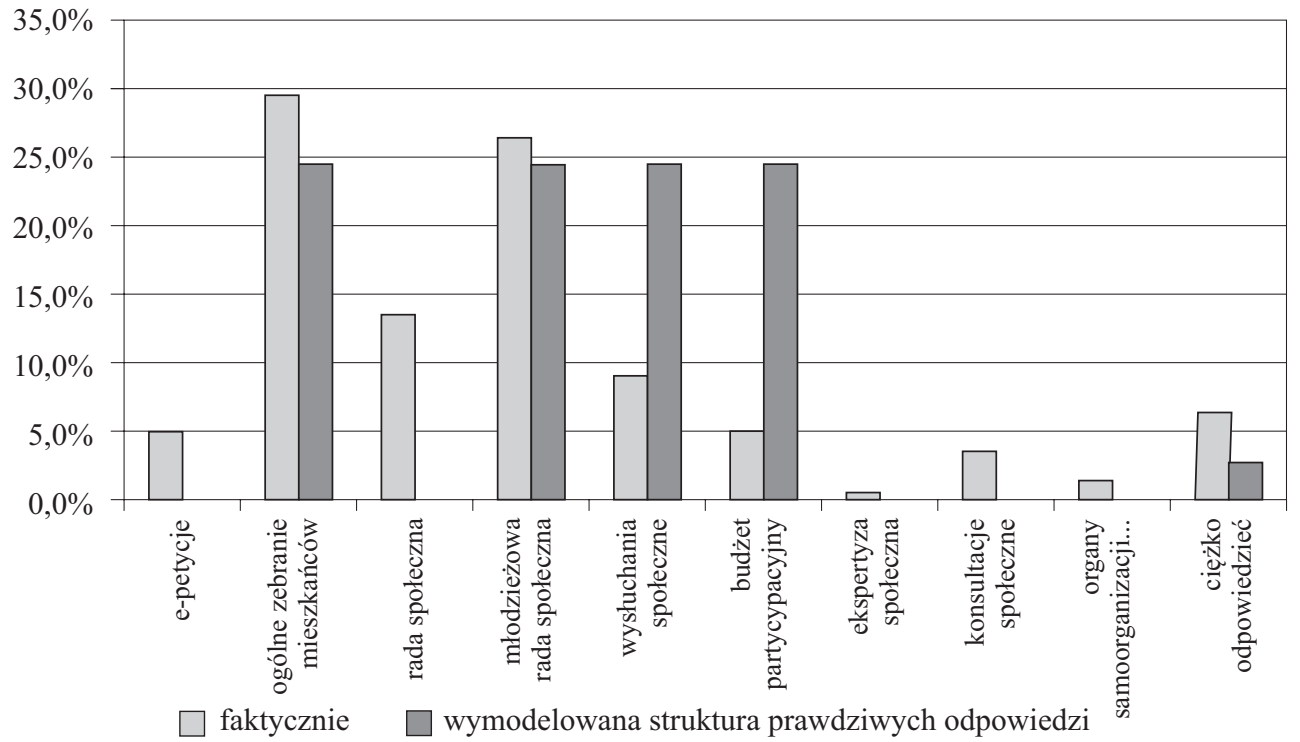

Źródło: Opracowanie własne - Atnazheva L. (2020), Analiza ankietowania mieszkańców hromad terytorialnych obwodu mikołajowskiego, biorących udział w Programie „Decentralizacja przynosi lepsze wyniki i efektywność" (DOBRE), realizowanym przez międzynarodową organizację Global Communities i finansowanym ze środków Agencji Stanów Zjednoczonych ds. Rozwoju Międzynarodowego (USAID). 
nistracyjnych chcieliby Państwo wdrożyć w swojej hromadzie?”. Dosyć często respondenci wskazywali te mechanizmy, które już funkcjonują w ich samorządach terytorialnych. Świadczy to o braku wiedzy społeczności na temat już istniejących mechanizmów, do czego one służą i jak z nich korzystać (wykres 5).

Wykres 5. Odpowiedzi respondentów z 11 hromad obwodu Mikołajowskiego na pytanie: „Jakie mechanizmy uczestnictwa mieszkańców w podejmowaniu decyzji administracyjnych chcieliby Państwo wdrożyć w swojej hromadzie?", \%

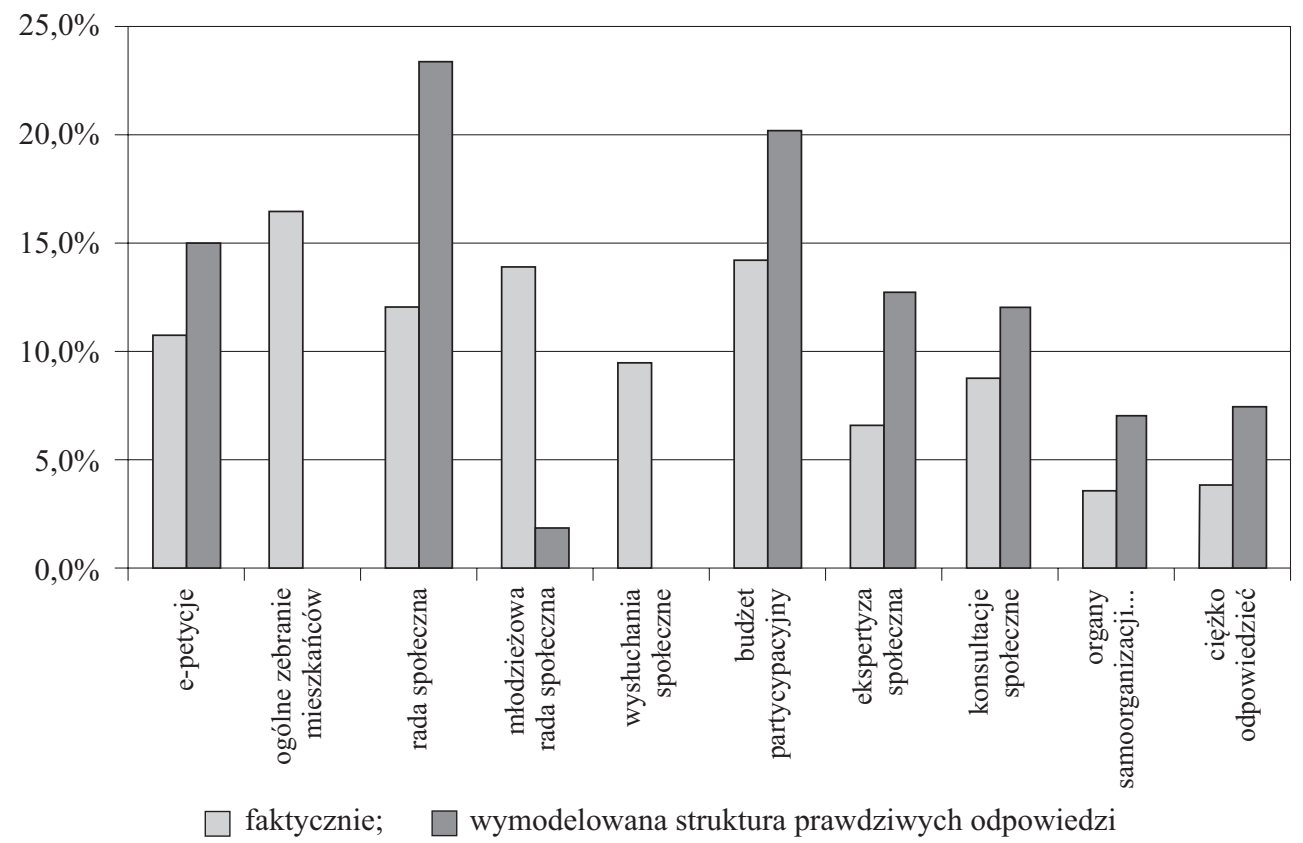

Źródło: Opracowanie własne - Atnazheva L. (2020), Analiza ankietowania mieszkańców hromad terytorialnych obwodu Mikołajowskiego, biorących udział w Programie „Decentralizacja przynosi lepsze wyniki i efektywność” (DOBRE), realizowanym przez międzynarodową organizację Global Communities i finansowanym ze środków Agencji Stanów Zjednoczonych ds. Rozwoju Międzynarodowego (USAID).

Za pomocą wykresu 6 przedstawiono odpowiedzi na powyższe pytania respondentów, zamieszkujących na terenie urzędowania Prybużaniwskiej Rady Wiejskiej, w porównaniu $\mathrm{z}$ faktycznym stanem funkcjonowania wymienionych mechanizmów w tej jednostce administracyjnej.

W Prybużaniwskiej Radzie Wiejskiej wcześniej zostały wdrożone takie mechanizmy, jak ogólne spotkania mieszkańców, Młodzieżowa Rada Społeczna, wysłuchania społeczne, wprowadzono budżet partycypacyjny. W ,idealnej” sytuacji respondenci nie powinni wymieniać w ankiecie tych form udziału mieszkańców w podejmowaniu decyzji, ponieważ one już funkcjonują.

Następne pytanie dotyczyło oceny przez respondentów własnego poziomu włączenia się $\mathrm{w}$ procesy podejmowania decyzji administracyjnych $\mathrm{w}$ ich hromadzie w skali od 0 (nie włączają się) do 5 (maksymalne zaangażowanie). Wyniki zostały odzwierciedlone na wykresie 7. 
Wykres 6. Odpowiedzi respondentów zamieszkujących na terenie urzędowania Prybużaniwskiej Rady Wiejskiej na pytanie: „Jakie mechanizmy uczestnictwa mieszkańców w podejmowaniu decyzji administracyjnych chcieliby Państwo wdrożyć w swojej hromadzie?”, \%

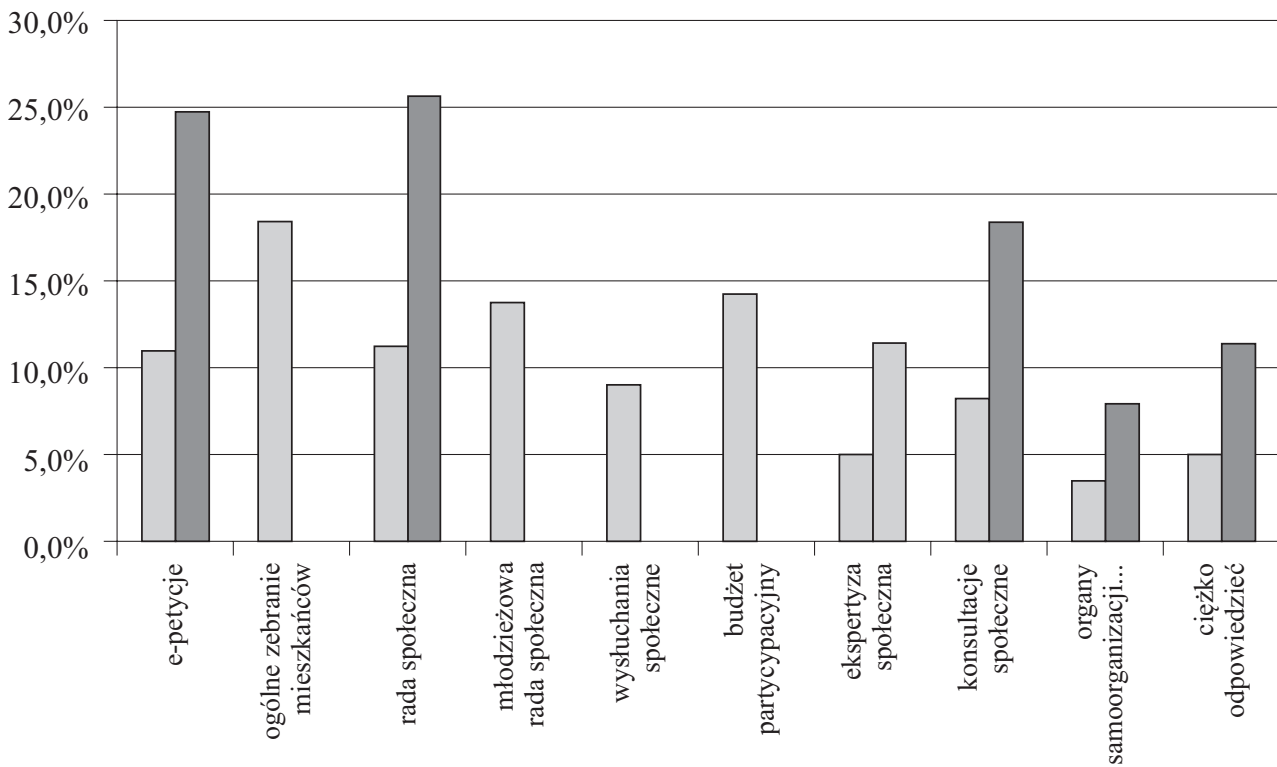

$\square$ faktycznie; $\square$ wymodelowana struktura prawdziwych odpowiedzi

Źródło: Opracowanie własne - Atnazheva L. (2020), Analiza ankietowania mieszkańców hromad terytorialnych obwodu Mikołajowskiego, biorących udział w Programie „Decentralizacja przynosi lepsze wyniki i efektywność" (DOBRE), realizowanym przez międzynarodową organizację Global Communities i finansowanym ze środków Agencji Stanów Zjednoczonych ds. Rozwoju Międzynarodowego (USAID).

Wykres 7. Podział oceny wlasnego poziomu zaangażowania respondentów w procesach podejmowania decyzji w hromadzie (11 hromad obwodu Mikołajowskiego)

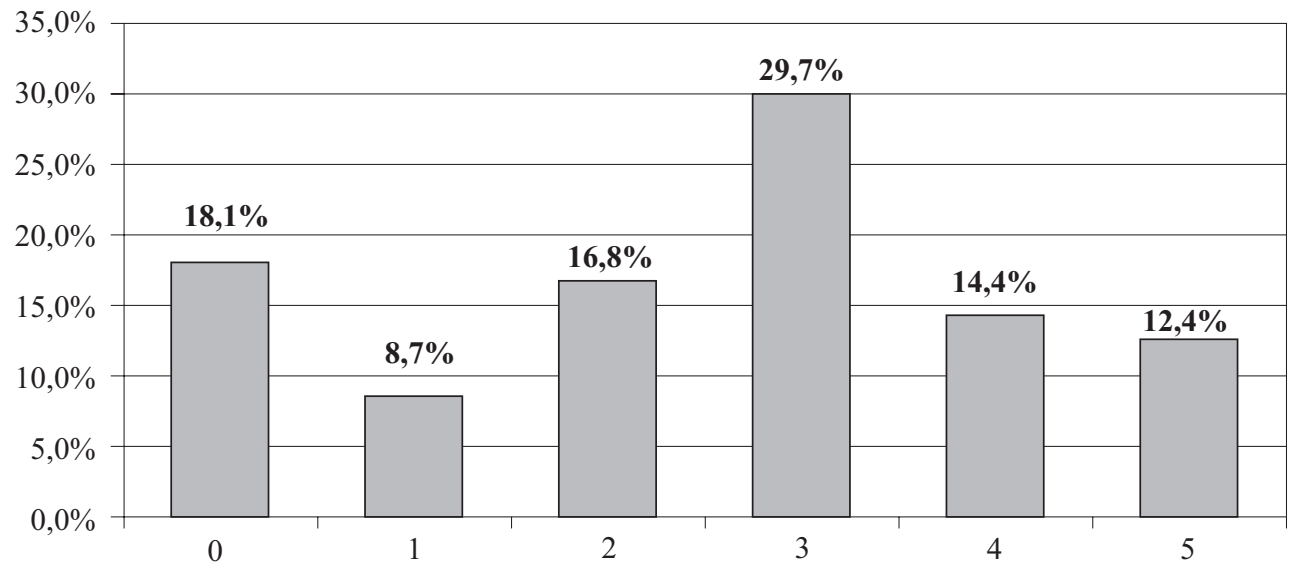

Źródło: Opracowanie własne - Atnazheva L. (2020), Analiza ankietowania mieszkańców hromad terytorialnych obwodu Mikołajowskiego, biorących udział w Programie „Decentralizacja przynosi lepsze wyniki i efektywność” (DOBRE), realizowanym przez międzynarodową organizację Global Communities i finansowanym ze środków Agencji Stanów Zjednoczonych ds. Rozwoju Międzynarodowego (USAID). 
Jak widać na wykresie 7, odpowiedzi respondentów bardzo się różnią. Osoby zaangażowane $\mathrm{w}$ procesy podejmowania decyzji na minimalnym poziomie ( $0-2$ oceny) - 43,6\%, w tym zupełnie nie zaangażowane (ocena 0 ) - 18,1\%. Maksymalny poziom zaangażowania (ocena 5) deklaruje 12,4\% respondentów. Za pomocą wykresu 8 odzwierciedlono podział wariantów odpowiedzi respondentów na pytanie, co mogłoby przyczynić się do zwiększenia ich poziomu włączania się do procesów podejmowania decyzji w hromadzie.

\section{Wykres 8. Podzial odpowiedzi respondentów na pytanie „Prosimy wskazać, co mogloby przyczynić się do zwiększenia Państwa poziomu włączenia się do procesów podjmowania decyzji w hromadzie? (11 hromad obwodu Mikolajewskiego)}

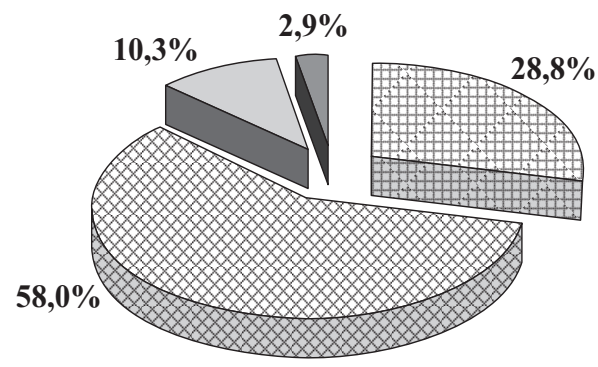

图 Szkolenia, dotyczące udziału w procesach podejmowania decyzji na poziomie lokalnym

图 Gdybym został(a) zaproszony(a) wyraziłbym(łabym) swoją opinię

$\square$ Nic, mnie wogóle to nie ciekawi

Pana/Pani wariant

Źródło: Opracowanie własne - Atnazheva L. (2020), Analiza ankietowania mieszkańców hromad terytorialnych obwodu Mikołajowskiego, biorących udział w Programie „Decentralizacja przynosi lepsze wyniki i efektywność” (DOBRE), realizowanym przez międzynarodową organizację Global Communities i finansowanym ze środków Agencji Stanów Zjednoczonych ds. Rozwoju Międzynarodowego (USAID).

Większość respondentów (58,0\%) wybrała odpowiedź: „Gdybym został/ła zaproszony/a, wyraziłbym/łabym swoją opinię". Kolejną najliczniejszą grupę stanowią osoby $(28,8 \%)$, które chciałyby zwiększyć swój udział w podejmowaniu decyzji administracyjnych na poziomie lokalnym za pomocą szkoleń. Jednocześnie wśród respondentów znalazły się osoby $(10,3 \%)$, które nie są zainteresowane jakimkolwiek udziałem w omawianych procesach. 2,9\% badanych wskazało swoje własne odpowiedzi, wśród których znalazły się: nie ma współpracy z władzą lokalną, nie informuje się mieszkańców, należy poświęcać więcej uwagi na włączenie młodzieży, brak czasu. Pojedynczy respondenci wskazywali, że aktywnie angażują się w procesy podejmowania decyzji na szczeblu lokalnym.

\section{Zakończenie}

We wszystkich hromadach, biorących udział w badaniu, miała miejsce podobna sytuacja: na prośbę nazwania mechanizmów uczestnictwa mieszkańców w podejmowaniu decyzji administracyjnych, funkcjonujących w ich jednostce samorządowej, respondenci wybierali nawet te, które w konkretnej hromadzie jeszcze nie zostały wdrożone, jednocześnie sugerowali wprowadzenie mechanizmów, które już istnieją. Świadczy to z jednej strony, że mieszkańcy posiadają niedostateczną wiedzę o specyfice poszczególnych mechanizmów oraz sposobach ich wykorzystania, a z drugiej strony - są niezo- 
rientowani w już istniejących możliwościach uczestnictwa w procesach podejmowania decyzji na szczeblu lokalnym.

Pomimo tego, że projekty międzynarodowe wspierające procesy decentralizacji na Ukrainie pomagają nowoutworzonym hromadom i stwarzają szersze możliwości udziału mieszkańców w procesach podejmowania decyzji administracyjnych, pojawia się potencjalne zagrożenie, że po zakończeniu ich działania nastąpi cofnięcie skutecznie wdrożonych reform. $Z$ tego powodu powinien powstać mechanizm, który stanie się bezpiecznikiem lub przynajmniej zminimalizuje możliwość powrotu do etapu wyjściowego.

Takim mechanizmem może się stać stworzenie w strukturze jednostek samorządowych osobnego wydziału odpowiadającego za wdrożenie reform związanych z decentralizacją albo przegląd funkcji już istniejących wydziałów, ich reformowanie i wprowadzenie ,dobrych praktyk” w celu monitoringu, analizy, zbioru danych oraz stworzenie warunków dla wewnętrznej koordynacji kierunków rozwoju.

\section{Bibliografia}

Atnazheva L. (2020), Analiza ankietowania mieszkańców hromad terytorialnych obwodu Mikołajowskiego, biorących udział w Programie „Decentralizacja przynosi lepsze wyniki i efektywność” (DOBRE), realizowanym przez międzynarodową organizację Global Communities i finansowanym ze środków Agencji Stanów Zjednoczonych ds. Rozwoju Międzynarodowego (USAID) [in Ukrainian].

Bacia E. (2010), Analiza metodologii i głównych wyników badań dotyczacych partycypacji obywatelskiej. Materiat roboczy, Warszawa, https://partycypacjaobywatelska.pl/wp-content/uploads/2015/08/2e_przeglad_badan_partycypacja_raport_desk_research.pdf, 4.10.2019.

Barber M. (2019), How to Run A Government: So that Citizens Benefit and Taxpayers Don't Go Crasy, thum. K. Dysa, Nash format, Kyiv [in Ukrainian].

Bevzenko L. (2014), Social Self-Organization and Mechanisms of Regulation of Social Behavior, „Ukrainskyi sotsiolohichnyi zhurnal”, nr 1-2, s. 6-17, http://www.irbis-nbuv.gov.ua/cgi-bin/ irbis_nbuv/cgiirbis_64.exe?I21DBN=LINK\&P21DBN=UJRN\&Z21ID $=\& S 21 \mathrm{REF}=10 \&$ $\mathrm{S} 21 \mathrm{CNR}=20 \& \mathrm{~S} 21 \overline{\mathrm{STN}}=1 \& \mathrm{~S} 21 \mathrm{FMT}=\mathrm{ASP} \_$meta\&C21COM$=\mathrm{S} \& 2 \_\mathrm{S} 21 \mathrm{P} 03=\mathrm{FILA}=\& 2$ S21STR=Ukrsocj_2014_1-2_3, 31.01.2020 [in Ukrainian].

Bevzenko L. D. (2002), Social self-organization. Synergetic Paradigm: Possibilities of Social Interpretations, Institut sotsiologii NAN Ukrainy, Kyiv [in Russian].

Bluj A., Jagaciak M., Perchuć-Żółtowska M., Pliszczyńska K. (2018), ABC partycypacji obywatelskiej - poradnik dla organizatorów procesów partycypacyjnych, Pracownia Badań i Innowacji Społecznych „Stocznia”, Warszawa, https://partycypacjaobywatelska.pl/wp-content/uploads/2018/11/ABC-Partycypacji.pdf, 31.01.2020.

Dorokh V. V., Chernii O. V. (2018), Forms of Public Participation in Decision-Making Processes, TOV „TVORY”, Vinnytsia, https://ldn.org.ua/wp-content/uploads/2019/03/Formy-uchasti-hromadskosti-A5.pdf, 31.01.2020 [in Ukrainian].

Krasnosilska A. O., Latsyba M. V., Voloshyna A. V., Kuprii V. O., Chermoshentseva N. M., Vashchuk O. L. (2013), State Policy to Promote The Development of Civil Society. Guidelines, Ahentstvo „Ukraina”, Kyiv [in Ukrainian].

Latsyba M. V., Lukeria I. M., Vashchuk-Ohdanska O. L. (2013), Local Democracy in Ukraine: New Standards, Ahentstvo „Ukraina”, Kyiv [in Ukrainian].

Law of Ukraine „,About Access to Public Information”, https://zakon.rada.gov.ua/laws/show/2939-17, 31.01.2020 [in Ukrainian]. 
Law of Ukraine ,About bodies of self-organization of the population”, https://zakon.rada.gov.ua/laws/ show/2625-14, 31.01.2020 [in Ukrainian].

Law of Ukraine „About Local Self-Government in Ukraine”, https://zakon.rada.gov.ua/laws/ show/280/97-\%D0\%B2\%D1\%80, 31.01.2020 [in Ukrainian].

Lukeria I., Tools for Citizens to Influence Local Government. Citizens in Action, USAID project, http:// www.ucipr.org.ua/index.php?option $=$ com_content \&view $=$ category\&layout $=$ blog $\& \mathrm{id}=42 \&$ Ite mid=205\&lang=ua, 31.01.2020 [in Ukrainian].

Luman N. (2004), Society as A Social System, thum. A. Antonovskii, Izdatelstvo „Logos”, Moskva [in Russian].

Luman N. (2007), Social Systems. Essay on General Theory, thum. I. D. Gadzieva, „Nauka”, SanktPeterburg [in Russian].

Lyska O. G., Participation of The Territorial Community in Local Self-Government, http://ifs.kbuapa. kharkov.ua/e-book/db/2008-1/doc/2/19.pdf, 2.02.2020 [in Ukrainian].

Martela B., Piwko J., Civic Activity on the Principle of Participatory Budget, http://www.pauci.org/ upload/files/gappb.pdf, 31.01.2020 [in Ukrainian].

Public Opinion Survey to Assess The Baseline Indicators of United Territorial Communities (2018), Participating in The Decentralization Brings Better Results and Effectiveness (DOBRE) Program, conducted by the Global Communities and funded by United States Agency for International Development (USAID), GfK Ukraine, viddil sotsialnykh ta politychnykh doslidzhen [in Ukrainian].

Public Participation in Decision-Making Processes at The Local Level (within the project „Citizen and the state: the development of partnership for effective governance in Ukrain”) (2012), Lenvit, Kyiv [in Ukrainian].

Pugachev V. P. (2019), Personnel Management of The Organization, Izdatelstvo Iurait, Moskva [in Russian].

Shapiro S. A. (2019), Organizational Behavior, Direkt-Media, Moskva-Berlin [in Russian].

Surina G. U. (2017), The Concept of „,Participation”: Genesis and Relevance, „Visnyk Dnipropetrovskoho uniwersytetu", nr 1, s. 55-60 [in Ukrainian].

Yevtukhova T. I., Lehenko Yu. V., Mishchenko R. I., Rodionov O. V., Rodionov O. V., Rudenko O. M. (2013), Public Participation in Decision-Making at The Local Level: A Textbook, DP „Ukrtekhinform", Kyiv [in Ukrainian].

\section{Inclusion of civil society in decision-making processes at local level: the impact of transnational projects}

\section{Summary}

The aim of this article is to identify factors, that directly affect the level of inhabitants participation in the decision-making processes at the local level, and to develop proposals, that will ensure the regular using of these mechanisms. Ukraine is currently in the decentralization process, which aims to increase the level of government, as a consequence of which towns and village councils have been consolited. The international projects have a big influense at such processes, helping newly consolited communities (administrative units) to implement best management practices, especially through the involvement of inhabitants in the decision-making processes.

The problem is that, inhabitants don't know, what kind of mechanisms exist for their participation in the decision-making processes at local level, and a local authorities don't sufficiently inform inhabitants about them. At this work, two main research methods are used: interviews and questionnaires. The analysis was based on the example of consolited communities, that participated in the Decentralization 
Brings Better Results and Efficiency Program (DOBRE), implemented by the international organization Global Communities and funded by the United States Agency for International Development (USAID). It was found, that inhabitants are don't know, what kind of mechanisms exist at their communities, that allow them to participate in the decision-making processes at the local level, anf how to use them.

In addition, it was found, that there is a correlation: the higher is a level of inhabitants knowledge how to access information about services for which local authorities are responsible, a higher is a level of inhabitants satisfaction by their participation in the decision-making processes at local level. A potential threat after the completion of international projects may be a step back from the changes, that have been implemented in communities. This situation can be prevented by creating a special department in local town or village council responsible for implementing changes in community or reviewing the functions of existing departments, reforming them to monitor, analyze, collect data and create conditions for coordination of development directions and implementation a good governance practices in community.

Key words: self-government, public participation, reform, decentralization 